\title{
Effect of Crop Establishment Methods and Weed Management Practices on Productivity, Economics and Nutrient Uptake in Direct Seeded Rice (Oryza sativa L.)
}

\author{
Shaheen Naz*, Ravi Nandan and D. K. Roy \\ Department of Agronomy, Dr. Rajendra Prasad Central Agricultural University, \\ Pusa-848125, India \\ *Corresponding author
}

\section{Keywords}

Direct seeded rice, Planting methods, Weed management, Nutrient uptake

Article Info

Accepted:

20 January 2020

Available Online:

10 February 2020

\section{A B S T R A C T}

A field experiment was conducted during kharif season at the Research Farm of Dr. Rajendra Prasad Central Agricultural University, Pusa (Samastipur), Bihar to investigate the effect of crop establishment methods and weed management practices on productivity, economics and nutrient uptake in direct seeded rice. The experiment was laid out in split plot design with three replications. Treatments constituted three planting methods in main plots $\left(\mathrm{M}_{1}\right.$ : Puddled, $\mathrm{M}_{2}$ : Zero-tillage and $\mathrm{M}_{3}$ : Dry-seeding ) and seven weed management practices in sub-plots $\left(\mathrm{T}_{1}\right.$ : Pendimethalin@1.0 Kg/ha(PE), $\mathrm{T}_{2}$ : Pretilachlor @ $1.5 \mathrm{Kg} / \mathrm{ha}(\mathrm{PE}), \mathrm{T}_{3}$ : Pendimethalin @ 1.0 $\mathrm{Kg} / \mathrm{ha}(\mathrm{PE}) f b$ one hand weeding at $30 \mathrm{DAS}, \mathrm{T}_{4}$ : Pretilachlor @ $1.5 \mathrm{Kg} / \mathrm{ha}(\mathrm{PE}) f b$ one hand weeding at $30 \mathrm{DAS}, \mathrm{T}_{5}$ : Dhaincha (Sesbania aculeata) fb 2,4-D @ $1 \mathrm{Kg} / \mathrm{ha}$ at $25 \mathrm{DAS}, \mathrm{T}_{6}$ : Two hand weedings at 20 and $40 \mathrm{DAS}, \mathrm{T}_{7}$ : Weedy check. The prominent weeds found in the experimental plot were among grasses like Cyanodon dactylon and Echinochloa colonum , Echinochloa crusgalli ; sedges like Cyperus rotundus, Cyperus iria and broad-leaved weeds like Caesulia axillaris, Eclipta alba, Phyllanthus niruri, Cannabis sativa, Physallis minima, Ageratum conyzoides, Dactyloctenium aegyptium were recorded. Maximum grain yield (35.77 $\mathrm{q} / \mathrm{ha}$ ) was recorded under planting method, puddled condition which established its superiority over zero-tillage (33.91 q/ha). Among weed management practices, two hand weedings at 20 and 40 DAS recorded the highest grain yield (38.20q/ha). Hand weeding twice alone was found more effective than pre-emergence application of herbicides along with one hand weeding. Among planting methods, puddled condition recorded maximum gross returns of ₹ 61,237/ha and net returns of ₹ 34,088/ha with a B:C ratio of 1.25 and was found significantly superior over zero-tillage and dry-seeding. Among weed management treatments, gross return (₹ 65,356/ha) was highest under two hand weedings at 20 and 40 DAS. Net return of ₹ $34,366 /$ ha was also recorded highest under two hand weedings at 20 and 40 DAS which however, was found statistically at par with Dhaincha (Sesbania aculaeta) $\mathrm{fb}$ 2,4-D at 25 DAS which generated a net return of ₹ 33,986/ha. As far as B:C ratio was concerned, Dhaincha (Sesbania aculaeta) $f b$ 2,4-D at 25 DAS recorded highest B:C ratio of 1.38 and was found significantly superior over rest of the weed management practices. The maximum $\mathrm{N}$ and $\mathrm{K}$ uptake by crop (70.99 and $65.05 \mathrm{~kg} / \mathrm{ha}$, respectively) was observed under planting method puddled condition which was significantly superior to zero-tillage and dry seeding. Although, higher P uptake $(14.20 \mathrm{~kg} / \mathrm{ha})$ was recorded under puddled condition but it was statistically at par with zero-tillage. 


\section{Introduction}

India is the second largest rice producing country in the world. The area and production under rice is $44.1 \mathrm{mha}$ and 99.5 million tones, respectively. In Bihar rice is cultivated in around $3.34 \mathrm{~m}$ ha with a production of 7.2 million tones and productivity of $21.58 \mathrm{q} / \mathrm{ha}$. The common method of rice cultivation in India is transplanting of the seedlings from nursery to main field which is very tedious and time consuming job. The higher cost and availability of farm labours invariably delay transplanting and often leads to transplanting of aged seedlings. The method of direct seeding escapes the transplanting and puddling operations which is an attractive and sustainable alternative to traditional transplanting of rice. Dry seeding saves labour cost by avoiding seedling raising, uprooting and transplanting. Despite its huge potential, the technology is highly impeded by high weed pressure with a broad spectrum compared to lowland flood irrigated conventional system. Direct seeded rice offers the advantage of faster and easier planting, ensure proper population, reduced labour and hence drudgery, 10-12 days earlier crop maturity, more efficient water and high tolerance to water-deficit and often higher profit in areas with assured water supply (De Datta, 1986). Weed infestation during early period of crop growth caused yield reduction to the tune of $33-74 \%$ or sometimes more depending upon the type of the weeds and their infestation (Tosh and Jena 1984; IRRI, 1997; Rao et al., 2007). Direct seeded rice (DSR) crop is subjected more weed competition for nutrient, light, water and space than transplanted rice because seeds of both crop and weed emerge almost at a same time, resulting in reduction in yield upto 50-90\% (Rao et al., 2007). Weed management is a primary concern in direct seeded rice (DSR) cropping because weed growth becomes a major constraint on crop yield. Uncontrolled weeds cause upto $80 \%$ reduction in grain yield and even complete failure of crop (Pandey et al., 2000 and Gopinath Kundu, 2008). DSR has a potential to replace the transplanted rice if weeds are controlled effectively. The yield loss due to poor weed management may vary from $10 \%$ to complete failure (Singh, 2005; Singh et al., 2008). The removal of competitive effect of weeds by weeding reduces inter-specific competition for resources more efficiently and enables the plants to utilize available resources more efficiently throughout the growth cycle, which in turn positively influences crop yield and biomass production. Thus, effective weed management is crucial for higher yield of crop. Weeding is traditionally done by hand in many parts of the world. Hand weeding is very easy and environment-friendly but tedious and highly labour intensive. At present, farmers very often fail to remove weeds due to unavailability of labour, especially at peak period. Moreover, the labour cost is increasing day by day which increases production cost making rice production as highly non-profitable business venture. In such conditions, herbicides offers the most practical and economic means of weed management. Reports show that herbicidal weed control is much cheaper and gives two or three times much more net benefit than manual weed control. Herbicide controls weeds very effectively and increases the yield of rice. Success of direct seeded rice depends largely of effective management of weeds. Various herbicides have been used for controlling weeds in direct seeded rice (Nandal and Om, 1998). Zero-tillage significantly reduced the $\mathrm{N}, \mathrm{P}$ and $\mathrm{k}$ depletion by weeds compared with the conventional tillage. Keeping the above facts in mind, the present experiment was planned to study the effect of crop establishment methods and weed management practices on productivity, economics and nutrient uptake in direct seeded rice. 


\section{Materials and Methods}

Afield experiment was carried out during kharif season of 2016. The factors under study comprised three planting methods i.e. $\mathrm{M}_{1^{-}}$ Puddled, $\mathrm{M}_{2}-$ Zero-tillage, $\mathrm{M}_{3}$ - Dry Seeding in main plots and 7 herbicidal treatments on direct seeded rice i.e.T. $T_{1}$ : Pendimethalin @ 1.0 $\mathrm{Kg} / \mathrm{ha}$ (PE), $\mathrm{T}_{2}$ : Pretilachlor @ $1.5 \mathrm{Kg} / \mathrm{ha}$ (PE), $\mathrm{T}_{3}$ : Pendimethalin @ $1.0 \mathrm{Kg} / \mathrm{ha}$ (PE) $f b$ one hand weeding at $30 \mathrm{DAS}, \mathrm{T}_{4}$ : Pretilachlor @ $1.5 \mathrm{Kg} / \mathrm{ha}(\mathrm{PE}) f b$ one hand weeding at 30 DAS, $\mathrm{T}_{5}$ : Dhaincha (Sesbania aculeata) $f b$ 2,4-D @ $1 \mathrm{Kg} / \mathrm{ha}$ at $25 \mathrm{DAS}, \mathrm{T}_{6}$ : Two hand weedings at 20 and 40 DAS, $\mathrm{T}_{7}$ : Weedy check in sub- plots with three replications. The soil of the experimental site was sandy loam with calcareous alluvium in nature and slightly alkaline $(\mathrm{pH}$ 8.38) in reaction and organic carbon $0.42 \%$, which was developed mainly by deposition of sediments of the river Budhi Gandak through the ages. The soil of the experimental field was low in available nitrogen $(213.24 \mathrm{Kg} / \mathrm{ha})$, phosphorus (18.94 $\mathrm{Kg} / \mathrm{ha})$ and potassium $(73.02 \mathrm{Kg} / \mathrm{ha})$. The nitrogen content in plant was determined by kjeldahl's method (Jackson, 1973). The grain and straw were separated and then grinded. The grinded material was digested in concentrated sulphuric acid using copper sulphate and potassium sulphate mixture as catalyst. The digested material was then distilled with 40 percent sodium hydroxide and distillate was collected in boric acid containing the mixed indicator. The content was estimated by titrating the distillate against N/20 sulphuric acid. The nitrogen uptake was calculated by multiplying the dry weight with nitrogen content. In order to get total uptake of nitrogen, the uptake values for grain and straw were added together. Total phosphorus uptake was determined in the extract by vando molybdate yellow color method (Jackson, 1973). The optical density (OD) was measured with photoelectric colorimeter at $470 \mathrm{~nm}$. The content was estimated with calibration
curve.The phosphorous uptake by grain and straw per hectare was calculated with the help of per cent value of phosphorus and yield of grain and straw. In order to get uptake of phosphorous, the uptake value for grain and straw were added together plot wise. The potassium content was determined with the help of flame photometer (Jackson, 1973) and was estimated with calibration curve. Total uptake of potassium by rice grain and straw was calculated by multiplying their relative contents with yield and values were added to know the total uptake of potassium in $\mathrm{kg} / \mathrm{ha}$. Economics of different treatments were calculated by taking into account the prevailing market price of inputs and produce (grain and straw).The gross return (₹/ha), net return (₹/ha) and Benefit : cost ratio were calculated for each treatment.

\section{Results and Discussion}

\section{Effect on crop yield}

Commensurate with the performances in terms of yield attributes, both grain and straw yield were the maximum $(35.77 \mathrm{q} / \mathrm{ha}$ and $48.63 \mathrm{q} / \mathrm{ha}$, respectively) under puddled planting method. This was due to reduction in crop-weed competition by providing poor oxygen supply which ultimately inhibits weed growth. Zerotillage gave significantly the least grain and straw yield (28.63 and 39.07q/ha). Among weed management treatments, two hand weedings at 20 and 40 DAS recorded highest grain yield $(38.20 \mathrm{q} / \mathrm{ha})$ which was followed by Pretilachlor $1.50 \mathrm{~kg} / \mathrm{ha}$ (PE) $f b$ one hand weeding at 30 DAS and was significantly superior to rest of the weed management practices. The results obtained may be explained on the basis of weed population, their dry matter accumulation and availability of space to each plant for their proper growth and development. The yield and yield attributes got their better expression under the condition of less competition, and 
comparatively better availability of inputs involved in manufacture of building blocks for plant bodies. The factors responsible for better expression of yield attributes and yields as a result of less competition with weeds are the same as described in details under the growth parameters. Simply one fact may be added here that the yield and yield attributes are more prone to weed competition than growth parameters as the growing meristematic tissues in rice plants remains below the ground level for greater part of vegetative growth. Whereas, the growing point in rice comes above the ground level and face more severe competition with weeds when yield attributes form in the plant body (Evans, 1979). Maximum harvest index (42.42\%) was recorded under $\mathrm{M}_{2}$ - zero-tillage whereas minimum was recorded under $\mathrm{M}_{1}$ - puddled $(42.33 \%)$. However, the treatment difference was non-significant.

Effect on nutrient uptake by crop and weeds

Nitrogen, phosphorus and potassium uptake by crop were affected significantly due to different planting methods and weed management practices. Uptake of $\mathrm{N}$ (70.99 $\mathrm{kg} / \mathrm{ha}), \mathrm{P}(14.20 \mathrm{~kg} / \mathrm{ha})$ and $\mathrm{K}(65.05 \mathrm{~kg} / \mathrm{ha})$ were higher in puddled conditions than zerotillage and dry-seeding. Amongst the three planting methods, puddled had an edge over $\mathrm{M}_{2}$ - zero-tillage and $\mathrm{M}_{3}$ - dry-seeding. However, P uptake by crop was found maximum under $\mathrm{M}_{1}$ - puddled which was statistically at par with $\mathrm{M}_{2}$ - zero-tillage but significantly superior to $\mathrm{M}_{3}$ - Dry seeding. Among weed management treatments, NPK uptake was the highest under $\mathrm{T}_{6}$ (two hand weedings at 20 and 40 DAS). While, nutrient uptake by weeds was complete reverse to that observed in case of crops. $\mathrm{M}_{1}$ - puddled showed least nutrient removal by weeds. Similarly, $\mathrm{T}_{6}$ (two hand weedings at 20 and 40 DAS) recorded less nutrient uptake by weeds than the other weed management treatments.
However, the lowest $\mathrm{K}$ uptake by weed was recorded under $M_{1}$ - puddled which was statistically at par with $\mathrm{M}_{2}$ - zero-tillage. There is not much to explain the behavior of treatments as crop uptake is directly a function of biological yield. The plots giving higher biological yields exhibited higher nutrient uptake and so on in other cases. Similarly, as the planting method- puddled offered greater opportunity to crop to come up and grow, their weeds took up a lion's share of nutrients from the plots. This was mainly due to better control of weeds during active crop growth stages, which helps in minimizing the cropweed competition and help the crop to utilise more nitrogen and other nutrients and led to better crop growth. Lower nutrient uptake might be due to severe competition offered by weeds for nutrients throughout the crop growth period which suppress the crop and severely affecting the crop growth. This result was in conformity with Singh and Tripathi (2007).

\section{Effect on economic aspects of rice cultivation}

As far as performances regarding growth and development was concerned, the planting method (puddled) out classed the other two planting methods in respect of gross return, net return as well as $\mathrm{B}$ : $\mathrm{C}$ ratio. The above mentioned planting method (puddled) generated a net return of₹34,088/ha with a $\mathrm{B}: \mathrm{C}$ ratio of 1.25 . As against this, the planting method zero-tillage fetched a net return of $₹ 31,572 /$ ha with a $\mathrm{B}: \mathrm{C}$ ratio of 1.19 . These two planting methods proved superior to dryseeding which had a net return of ₹22,867/ha having a $\mathrm{B}: \mathrm{C}$ ratio of 0.86 .Puddled which was found significantly superior to zero-tillage and dry-seeding with regards to net return, gross return and $\mathrm{B}: \mathrm{C}$ ratio as the puddled conditions was found effective in minimising weed growth and maximising yield and economic return of direct-seeded rice. 
Table.1 Effect of different treatments on yield and economics of direct seeded rice

\begin{tabular}{|c|c|c|c|c|c|c|}
\hline Treatments & $\begin{array}{l}\text { Grain yield } \\
\text { (Kg/ha) }\end{array}$ & $\begin{array}{c}\text { Straw yield } \\
(\mathrm{Kg} / \mathrm{ha})\end{array}$ & $\begin{array}{c}\text { Harvest index } \\
(\%)\end{array}$ & $\begin{array}{c}\text { Gross return } \\
\text { (₹/ha) }\end{array}$ & $\begin{array}{l}\text { Net return } \\
\text { (₹/ha) }\end{array}$ & $\mathrm{B}: \mathrm{C}$ ratio \\
\hline \multicolumn{7}{|l|}{ Main plots } \\
\hline Puddling & 35.77 & 48.63 & 42.33 & 61237 & 34088 & 1.25 \\
\hline Zero-tillage & 33.91 & 45.93 & 42.42 & 58022 & 31572 & 1.19 \\
\hline Dry seeding & 28.63 & 39.07 & 42.36 & 49218 & 22867 & 0.86 \\
\hline $\mathrm{CD}(\mathrm{P}=\mathbf{0 . 0 5})$ & 1.50 & 2.11 & NS & 1628 & 1628 & 0.06 \\
\hline \multicolumn{7}{|l|}{ Sub-plots } \\
\hline Pendimethalin 1.0 kg/ha (PE) & 32.11 & 43.41 & 42.44 & 54906 & 29850 & 1.19 \\
\hline Pretilachlor 1.5 kg/ha (PE) & 32.62 & 44.47 & 42.29 & 55837 & 30947 & 1.24 \\
\hline $\begin{array}{l}\text { Pendimethalin } 1.0 \mathrm{~kg} / \mathrm{ha}(\mathrm{PE}) \\
\mathrm{fb} \text { one hand weeding at } 30 \\
\text { DAS }\end{array}$ & 35.84 & 48.31 & 42.54 & 61214 & 32159 & 1.11 \\
\hline $\begin{array}{l}\text { Pretilachlor } 1.5 \mathrm{~kg} / \mathrm{ha}(\mathrm{PE}) \mathrm{fb} \\
\text { one hand weeding at } 30 \text { DAS }\end{array}$ & 36.20 & 49.21 & 42.35 & 61970 & 33080 & 1.14 \\
\hline $\begin{array}{l}\text { Dhaincha (Sesbania aculeata) } \\
f b \text { 2,4-D } 1 \mathrm{~kg} / \mathrm{ha} \text { at } 25 \text { DAS }\end{array}$ & 34.32 & 46.36 & 42.49 & 58664 & 33986 & 1.38 \\
\hline $\begin{array}{l}\text { Two hand weedings at } 20 \text { and } \\
40 \text { DAS }\end{array}$ & 38.27 & 51.74 & 42.45 & 65356 & 34366 & 1.11 \\
\hline Weedy check & 20.28 & 28.31 & 42.03 & 35165 & 12175 & 0.53 \\
\hline $\mathrm{CD}(\mathrm{P}=0.05)$ & 1.14 & 1.88 & NS & 1820 & 1820 & 0.07 \\
\hline
\end{tabular}


Table.2 Effect of different treatments on NPK uptake by crop and weeds

\begin{tabular}{|c|c|c|c|c|c|c|}
\hline \multirow[t]{2}{*}{ Treatments } & \multicolumn{3}{|c|}{ NPK uptake by crop (kg/ha) } & \multicolumn{3}{|c|}{ NPK uptake by weeds (kg/ha) } \\
\hline & N uptake & P uptake & K uptake & N uptake & P uptake & K uptake \\
\hline \multicolumn{7}{|l|}{ Main plots } \\
\hline Puddling & 70.99 & 14.20 & 65.05 & 17.28 & 3.97 & 4.11 \\
\hline Zero-tillage & 66.03 & 12.26 & 60.06 & 18.67 & 4.03 & 4.41 \\
\hline Dry seeding & 54.85 & 9.55 & 48.75 & 20.32 & 4.37 & 4.83 \\
\hline $\mathrm{CD}(\mathrm{P}=\mathbf{0 . 0 5})$ & 1.34 & 2.06 & 1.44 & NS & NS & 0.44 \\
\hline \multicolumn{7}{|l|}{ Sub-plots } \\
\hline Pendimethalin 1.0 kg/ha (PE) & 59.79 & 10.21 & 52.75 & 19.24 & 4.15 & 4.50 \\
\hline Pretilachlor 1.5 kg/ha (PE) & 62.60 & 10.90 & 56.19 & 18.34 & 4.06 & 4.33 \\
\hline $\begin{array}{l}\text { Pendimethalin } 1.0 \mathrm{~kg} / \mathrm{ha}(\mathrm{PE}) \\
f b \text { one hand weeding at } 30 \\
\text { DAS }\end{array}$ & 70.92 & 13.81 & 64.21 & 17.40 & 3.90 & 4.20 \\
\hline $\begin{array}{l}\text { Pretilachlor } 1.5 \mathrm{~kg} / \mathrm{ha}(\mathrm{PE}) \mathrm{fb} \\
\text { one hand weeding at } 30 \text { DAS }\end{array}$ & 73.68 & 14.99 & 67.58 & 16.89 & 3.91 & 4.18 \\
\hline $\begin{array}{l}\text { Dhaincha (Sesbania aculeata) } \\
\text { fb 2,4-D } 1 \mathrm{~kg} / \mathrm{ha} \text { at } 25 \text { DAS }\end{array}$ & 66.76 & 12.49 & 61.87 & 17.42 & 3.93 & 4.29 \\
\hline $\begin{array}{l}\text { Two hand weedings at } 20 \text { and } \\
40 \text { DAS }\end{array}$ & 79.73 & 17.21 & 72.17 & 14.30 & 3.45 & 3.62 \\
\hline Weedy check & 34.21 & 4.39 & 30.90 & 27.71 & 5.48 & 6.04 \\
\hline $\mathrm{CD}(\mathrm{P}=0.05)$ & 2.51 & 1.23 & 2.60 & 1.40 & 0.59 & 0.45 \\
\hline
\end{tabular}


The results obtained in terms of economics find support to the works of Singh and Kumar (2002), Sanjay et al., (2008), Pandey et al., (2009) and Singh and Singh (2010). Two hand weedings is still the most effective means to manage weeds in most of the crops, but ever increasing efficacy of newly evolved herbicides. Quite in league with experimental results, two hand weedings at 20 and 40 DAS $\left(\mathrm{T}_{6}\right)$ still holds top position in growth, development and yield. Two hand weedings at 20 and 40 DAS) had the highest gross return to its credit ( $₹ 65,356 / \mathrm{ha}$ ) followed by Pretilachlor $1.50 \mathrm{~kg} / \mathrm{ha}(\mathrm{PE}) f b$ one hand weeding at 30 DAS (₹61,970/ha) and was significantly superior to rest of the weed management practices. Two hand weedings at 20 and 40 DAS) recorded highest net return (₹34,366/ha) though was found statistically at par with $\mathrm{T}_{5}-$ Dhaincha (Sesbania aculeata) $\mathrm{fb}$ 2,4-D $1 \mathrm{~kg} / \mathrm{ha}$ at 25 DAS (₹33,986/ha) and $\mathrm{T}_{4}$ - Pretilachlor $1.50 \mathrm{~kg} / \mathrm{ha}(\mathrm{PE}) f b$ one hand weeding at 30 DAS (₹33,080/ha). Interestingly, two hand weedings at 20 and 40 DAS which remained comparable with treatment Pretilachlor $1.50 \mathrm{~kg} / \mathrm{ha}(\mathrm{PE}) f b$ one hand weeding at 30 DAS in almost all observations pertaining to yield attributes, gross and net return. As far as B:C ratio was concerned, Dhaincha (Sesbania aculeata) $\mathrm{fb}$ 2,4-D at 25 DAS fetched highest B:C ratio due to less cost of cultivation and more grain and straw yields.

\section{References}

De Datta, S.K. 1986. Technology development and the spread of directseeded flooded rice in South-east Asia. Experimental Agriculture 22: 417-26.

Evans, L.T., Wardlaw, I.F. and Fischer, R.A. 1979. Wheat crop physiology. Blackie and Sons Publishers Pvt. Ltd., Bombay, pp. 101-135.

Gopinath, K.A. and Kundu, S. 2008. Evaluation of metsulfuron-methyl+ chlorimuron-ethyl for weed control in direct-seeded rice (Oryza sativa). Indian Journal of Agricultural Sciences 78(5): 466-69.

Jackson, M. L. 1973. Soil chemical analysis, Prentice hall of India Private Limited, New Delhi, India.

Nandal, D.P. and Hari, Om. 1998. Weed control in direct-seeded puddle rice. Indian Journal of Weed Science30: 1820.

Pandey, A.K., Prakash, V., Singh, P., Prasad, K., Singh, R.D. and Mani, V.P. 2000. Weed management in major crops of North-western Himalayas. Technical Bulletin 16.VPKAS, Almora. 66 p.

Pandey, D. K., Gangwar, K. S. and Chaudhary, V. P. 2009. Weed management in direct sown rice. Oryza Vol. 46. No. 2 (165-166).

Rao, A. N., Jonshon, D. E., Shivaprasad. B., Ladha, J.K. and Mortimer, A. M. 2007. Weed management in direct - seeded rice. Advances in Agronomy 93: 153255.

Sanjay, M.T., Setty, L.K., Prabhakara and Nanjappa, H.V. 2008. Investigation of crop establishment methods and weed management practices on productivity and economics in rice. Mysore Journal of Agriculture Science 42(1): 60-66.

Singh, C.V., Ghosh, B.C., Mittra, B.N. and Singh, R.K. 2008. Influence of nitrogen and weed management on the productivity of upland rice. Journal of Plant Nutrition and Soil Science171(3): 466-70.

Singh, G.; Singh, R.G.; Singh, O.P.; Thakur, T.; Mehta, R.K.; Kumar, V. and Singh, P.P. 2005. Effect of weed management practices on direct seeded rice (Oryza sativa) under puddled lowlands. Indian Journal of Agronomy 50(1): 35-37.

Singh, K. andTripathi, H.P. 2007. Effect of nitrogen and weed-control practices on performance of irrigated direct seeded 
rice (Oryza sativa). Indian Journal of Agronomy 52(3): 231-234.

Singh, Mandhata and Singh, R. P. 2010. Influence of crop establishment and weed management practices on yield and economics. Indian Journal of Agronomy 55(3): 224-229.
Singh, R. Singh, M. K. and Kumar, S. 2002. Weed management in rice. Farmers Digest, PP. 5 -12.

Tosh, G.C. and Jena, H.C. 1984. Weed control in dry seeded lowland rice bentazon combined with 2,4-D. IRRN 9: 19.

\section{How to cite this article:}

Shaheen Naz, Ravi Nandan and D. K. Roy. 2020. Effect of Crop Establishment Methods and Weed Management Practices on Productivity, Economics and Nutrient Uptake in Direct Seeded Rice (Oryza sativa L.). Int.J.Curr.Microbiol.App.Sci. 9(02): 3002-3009.

doi: https://doi.org/10.20546/ijcmas.2020.902.344 